\title{
Bacillus sp. L324-92 for Biological Control of Three Root Diseases of Wheat Grown with Reduced Tillage
}

\author{
Dal-Soo Kim, R. James Cook, and David M. Weller
}

First author: Department of Plant Pathology, Washington State University, Pullman 99164-6430; and second and third authors: Agricultural Research Service, U.S. Department of Agriculture, Pullman, WA 99164-6430.

Current address of D.-S. Kim: Specialty Chemical Research Institute, LG Chemical Ltd./Research Park, P.O. Box 61, Yusung Science Town, Taejon 305-380, Korea.

Accepted for publication 7 February 1997.

\begin{abstract}
Kim, D.-S., Cook, R. J., and Weller, D. M. 1997. Bacillus sp. L324-92 for biological control of three root diseases of wheat grown with reduced tillage. Phytopathology 87:551-558.

Strain L324-92 is a novel Bacillus sp. with biological activity against three root diseases of wheat, namely take-all caused by Gaeumannomyces graminis var. tritici, Rhizoctonia root rot caused by Rhizoctonia solani AG8, and Pythium root rot caused mainly by Pythium irregulare and P. ultimum, that exhibits broad-spectrum inhibitory activity and grows at temperatures from 4 to $40^{\circ} \mathrm{C}$. These three root diseases are major yieldlimiting factors for wheat in the U.S. Inland Pacific Northwest, especially wheat direct-drilled into the residue of a previous cereal crop. Strain L324-92 was selected from among approximately 2,000 rhizosphere/rhizoplane isolates of Bacillus species isolated from roots of

species and anastomosis groups, and Pythium species tested on agar at $15^{\circ} \mathrm{C}$; provided significant suppression of all three root diseases at $15^{\circ} \mathrm{C}$ in growth chamber assays; controlled either Rhizoctonia root rot, takeall, or both; and increased yields in field tests in which one or more of the three root diseases of wheats were yield-limiting factors. The ability of L324-92 to grow at $4^{\circ} \mathrm{C}$ probably contributes to its biocontrol activity on direct-drilled winter and spring wheat because, under Inland Northwest conditions, leaving harvest residues of the previous crop on the soil surface keeps soils cooler compared with tilled soils. These results suggest that Bacillus species with desired traits for biological control of wheat root diseases are present within the community of wheat rhizosphere microorganisms and can be recovered by protocols developed earlier for isolation of fluorescent Pseudomonas species effective against take-all.
\end{abstract} wheat collected from two eastern Washington wheat fields that had long histories of wheat. Roots were washed, heat-treated $\left(80^{\circ} \mathrm{C}\right.$ for $\left.30 \mathrm{~min}\right)$, macerated, and dilution-plated on 1/10-strength tryptic soy agar. Strain L324-92 inhibited all isolates of G. graminis var. tritici, Rhizoctonia
Additional keywords: conservation tillage, plant growth-promoting rhizobacteria, soilborne pathogens, Triticum aestivum.
Currently, eight species of microorganisms are registered by the U.S. Environmental Protection Agency for commercial use against soilborne plant pathogens in the United States (12). These include two fungi (Gliocladium virens G-21 and Trichoderma harzianum KRL-AG2), three Gram-negative bacteria (Agrobacterium radiobacter K84, Pseudomonas fluorescens EG1053, and Berholdera cepacia type Wisconsin), and three Gram-positive bacteria (Bacillus subtilis GB03, B. subtilis MBI 600, and Streptomyces griseoviridis K61). Except for A. radiobacter K84, each of these microorganisms are intended to control damping-off diseases and improve stand establishment and seedling vigor. Although not yet in commercial use, major scientific and technical advances have also been made in the use of biocontrol strains introduced on or with the seed and subsequently expected to colonize the roots as they grow into the soil and survive for as long as necessary to protect against root infections from soilborne inoculum (44). Greatest success with this strategy will likely depend on strains specifically selected for their rhizosphere competence on

Corresponding author: D. M. Weller; E-mail address: wellerd@mail.wsu.edu

Mention of a trademark or proprietary product does not constitute a guarantee or warranty of the product by the U.S. Department of Agriculture, and does not imply approval to the exclusion of other products that may also be suitable.

Publication no. P-1997-0321-01R

This article is in the public domain and not copyrightable. It may be freely reprinted with customary crediting of the source. The American Phytopathological Society, 1997. the host plant(s) targeted for protection, as well as their ability to protect against the targeted soilborne pathogen(s).

Wheat planted directly (direct-drilled or "no-till") into standing stubble of wheat, barley, or herbicide-killed grass, as practiced for conservation of soil, water, and energy resources, is subject to damage from one or more of at least three root diseases $(9,35,38)$ : take-all caused by Gaeumannomyces graminis var. tritici (29); Rhizoctonia root rot caused by Rhizoctonia solani AG8 (30,36,39, $46)$ and $R$. oryzae $(27,30)$; and Pythium root rot caused by several Pythium species (4), most notably $P$. irregulare and $P$. ultimum $(15,16)$. As with other major food crops, the trend worldwide is away from the long and often complex crop rotations and toward intensive, or continuous, wheat or continuous cereals (winter and spring wheat and barley rotations). Barley is also a host and can sustain damage from the pathogens responsible for these three root diseases, especially $R$. solani AG8 (30). Method of planting (34) and timely elimination of volunteer and grass weed hosts (35, 38) can provide considerable control, but these cultural practices by themselves are not sufficient to fully manage all three root diseases and achieve the high yields possible in these cropping systems (7).

The potential for use of antibiotic-producing fluorescent Pseudomonas species to control take-all when introduced into the rhizosphere as a seed inoculation has been well documented (32, $37,45)$. Some of the most effective strains have been isolated from the rhizosphere of wheat growing in soil from fields in which take-all occurred but then declined with continuous cropping of wheat $(1,8)$. This approach follows a protocol proposed by Baker and Cook (1), which is to seek effective antagonists in which the 
target pathogen is present but produces little or no disease in spite of a susceptible host and apparently favorable environment.

Bacillus species, as a group, offer several advantages over fluorescent pseudomonads and other Gram-negative bacteria as seed inoculants for protection against root pathogens, including longer shelf life, because of their ability to form endospores and the broad-spectrum activity of their antibiotics. One of the best known examples is B. subtilis A13, isolated more than 25 years ago in Australia (2). This strain was selected based on in vitro inhibitory activity to all of nine pathogens tested and was subsequently shown to promote growth of cereals, sweet corn, carrots, and bedding plants when applied as a seed inoculant (28). B. subtilis GB03, sold today in the United States as Kodiak (Gustafson, Inc., Dallas) for control of damping-off mainly of cotton, is a "cottonadapted variant" of B. subtilis A13 (22). Broad-spectrum activity is needed on crops such as direct-drilled wheat in which roots may be infected with any of eight to 10 species representing three major classes (acomycotina, basidiomycotina, and oomycetes) of fungi. Campbell and Faul (3) showed that take-all was suppressed and hyphae of $G$. graminis var. tritici were lysed on roots of wheat inoculated in field plots with a suspension of cells of $B$. cereus var. mycoides isolated originally from a take-all decline soil; but whether this bacterium can control take-all in naturally infested fields when introduced as a seed treatment is not known.

Bacillus species, as a group, have been considered less effective as rhizosphere colonists compared with fluorescent pseudomonads. However, there is a growing list of reports of rhizosphere colonization and root disease control with Bacillus species introduced as seed inoculants, including $B$. cereus UW85 for control of damping-off of alfalfa $(13,14), B$. megaterium B153-2-2 for control of Rhizoctonia root rot of soybean $(18,19,20)$, B. subtilis GB03 for control of damping-off of cotton (22), and B. mycoides for control of wheat take-all (23). In China, success has been reported for the use of Bacillus species as "yield-increasing bacteria" when introduced as a seed inoculant on several crops including wheat and rice (50). Considering the diversity of Bacillus species in soils, and given the findings of Mavingui et al. (25) that populations of $B$. polymyxa in the rhizosphere and rhizoplane are different from those in bulk soil, it should be possible to isolate strains of Bacillus species that are both wheat rhizosphere-competent and biologically active against a broad spectrum of wheat root pathogens.

The purpose of this study was to determine (i) whether strains of Bacillus species effective against take-all, when introduced into the rhizosphere, could be obtained by screening strains from fields cropped continuously to wheat (wheat root enrichment) and (ii) whether a single Bacillus strain could be obtained with activity against the three groups of wheat root pathogens responsible for take-all, Rhizoctonia root rot, and Pythium root rot, including with ability to grow at the low temperatures encountered in the Inland Northwest with direct-drilled winter and spring wheat.

\section{MATERIALS AND METHODS}

Organisms and their culture. All strains of $R$. solani, $R$. oryzae, G. graminis var. tritici, and Pythium species were obtained from the collection of the USDA-ARS, Root Disease and Biological Control Research Unit at Pullman, WA. These fungi were routinely grown on dilute homemade potato dextrose agar (PDA) and stored at $4^{\circ} \mathrm{C}$. Oat-kernel inoculum of each pathogen was prepared as described previously (49).

Strains of Bacillus and Pseudomonas species were stored at $-80^{\circ} \mathrm{C}$ in $40 \%$ glycerol-containing nutrient broth-yeast extract (NBY) broth (42). Pseudomonas fluorescens-putida strain Q69c80 was included in field studies because of its known biocontrol activity against take-all (32; D. M. Weller and R. J. Cook, unpublished data). Bacillus strains taken from storage were grown on tryptic soy agar (TSA) (24); strain Q69c-80 was grown on King's medium B agar (17).
Isolation of root-associated, heat-resistant bacteria. Wheat seedlings in the one- to three-leaf stage were collected from fields near Lind and Pullman, WA, that had been cropped annually to wheat for 25 and 12 years, respectively, after decades of wheat/ fallow or wheat in various crop rotations. Fragments of four seminal roots ( 0 to $2.5 \mathrm{~cm}$ from the seed and 5 to $8 \mathrm{~cm}$ deep, depending on the depth of sowing) were excised and then washed four times, each for $30 \mathrm{~min}$, with $50 \mathrm{ml}$ of fresh sterile water in a $250-\mathrm{ml}$ flask on a rotary shaker $(250 \mathrm{rpm})$ at $10^{\circ} \mathrm{C}$. Washed root segments were placed in a test tube with $5 \mathrm{ml}$ of $0.0125 \mathrm{M}$ phosphate buffer (1.21 $\mathrm{g}$ of $\mathrm{KH}_{2} \mathrm{PO}_{4}, 2.80 \mathrm{~g}$ of $\mathrm{K}_{2} \mathrm{HPO}_{4}$, and 1 liter of deionized water; $\mathrm{pH}$ 7.1) and heat-treated at $80^{\circ} \mathrm{C}$ for $30 \mathrm{~min}$ in a water bath. Heat-treated root segments were macerated in a mortar, resuspended in $5 \mathrm{ml}$ of phosphate buffer, and aliquots $(100 \mu \mathrm{l})$ from a serial dilution were plated on $1 / 10$ TSA.

Approximately 2,000 colonies (1,500 isolates from the Lind site and 500 isolates from the Pullman site) were selected for testing. To screen for in vitro antibiosis, four isolates were spotted with sterile toothpicks around the edge of a plate of $1 / 10$ TSA. Plates were incubated for 2 days at $15^{\circ} \mathrm{C}$, and one 8-mm-diameter agar disk of $R$. solani AG8 isolate C-1 from a 1-week-old PDA culture was placed in the center of the plate. After another week, the width of the inhibition zone between each bacterial colony and the fungal colony was measured. The original 310 isolates showing inhibition to $R$. solani AG8 were tested again on dilute $(1 / 5$ strength) PDA for in vitro inhibition of $G$. graminis var. tritici isolate Pullman A and P. irregulare ATCC 11120. Finally, Bacillus strain L324-92 was tested against 36 isolates of G. graminis var. tritici, 41 isolates of $R$. solani (seven AGs), five isolates of $R$. oryzae, and 14 isolates of Pythium species (11 species). Two $10-\mu \mathrm{l}$ aliquots of a cell suspension of L324-92 were spotted at opposite sides of a $1 / 5$ PDA plate, and the plates were incubated for 2 days at $15^{\circ} \mathrm{C}$. Each test fungus was placed in the center of a plate. After 1 week of incubation at $15^{\circ} \mathrm{C}$, the radius of the fungal colony in the direction with bacterial colonies was measured and compared with that in the direction with no bacterial colonies.

Identification of Bacillus species. Selected Bacillus strains were examined for Gram reaction, oxygen requirement, spore formation, and catalase reaction (40). Oxygen requirement of each strain was tested in a jar with an anaerobic atmosphere (BBL GasPak Plus; Becton Dickinson Co., Cockeysville, MD). Endospore formation was tested on NBY agar medium amended with $0.003 \%$ (wt/vol) manganese sulfate (21). Bacterial cultures were spread on the medium, incubated at $25^{\circ} \mathrm{C}$ for 3 days, and the cells were then observed for endospore formation under a phase-contrast microscope. Bacillus strains (L324-92, L331-92, and P206-92) also were evaluated using the API 50 CHB system (SA Montalieu, Vericieu, France). Strain L324-92 was sent to both Microbial ID, Inc. (Newark, DE) and American Type Culture Collection (ATCC; Rockville, MD) for identification.

Growth of Bacillus species. The growth of Bacillus strains L324-92 and B. subtilis A13 (2) were compared at 10, 15, and $20^{\circ} \mathrm{C}$ in NBY broth; growth of each bacterium was measured spectrophotometrically at $600 \mathrm{~nm}\left(\mathrm{~A}_{600}\right)$ every $12 \mathrm{~h}$. Fifty microliters of each strain, grown overnight in $5 \mathrm{ml}$ of NBY broth $\left(\mathrm{A}_{600}=0.1\right)$ at 21 to $24^{\circ} \mathrm{C}$, were transferred individually into 50 $\mathrm{ml}$ of NBY broth in 250-ml Erlenmeyer flasks and placed on a rotary shaker at $150 \mathrm{rpm}$ at each temperature. Each treatment was replicated three times, and the experiment was repeated.

Bacterial seed treatment. Seeds of spring wheat (cv. Penawawa) were disinfected as described by Mazzola and Cook (26) and coated with bacteria by methods similar to those described by Weller et al. (48). Briefly, bacterial strains were grown as a lawn on NBY agar medium for $48 \mathrm{~h}$ at 21 to $24^{\circ} \mathrm{C}$. For growth chamber assays, $4 \mathrm{ml}$ of $0.5 \%$ (wt/vol) methylcellulose were added to the plate, and the cells were scraped free. The methylcellulose suspension with vegetative cells of each bacterium was then mixed with $10 \mathrm{~g}$ of seed in a petri plate, and the coated seeds were dried 
for 30 min under a stream of sterile air. For field studies, the amounts of bacteria and methylcellulose were increased to treat a larger amount of seeds (32). The initial population of each strain on the seeds was determined by dilution-plating on $1 / 10$ TSA immediately following the treatment. Colonies were counted after 2 to 3 days of incubation at 21 to $24^{\circ} \mathrm{C}$.

Growth chamber assay for biocontrol activity against root diseases. Tube assays $(31,48)$ were used to screen bacterial isolates for their biocontrol activity against take-all and Rhizoctonia root rot in the growth chamber. The assay used plastic, tapered tubes $(2.5 \mathrm{~cm}$ diameter $\times 16.5 \mathrm{~cm}$ long), with holes at their bottoms, that were supported in a hanging position in a plastic rack. Each tube was plugged with a cotton ball and then filled half full with sterile vermiculite followed by $10 \mathrm{~g}$ of either steamed or raw soil infested with oat-kernel inoculum of each pathogen. When Rhizoctonia root rot was the target disease, one whole oat kernel colonized with $R$. solani AG8 isolate C-1 was placed on the top of $10 \mathrm{~g}$ of soil in the tubes and covered with another $10 \mathrm{~g}$ of the same soil. When take-all was the target disease, $10 \mathrm{~g}$ of soil infested with $1.0 \%$ (wt/wt) oat-kernel inoculum (particle size: 0.25 to 0.5 $\mathrm{mm}$ ) of G. graminis var. tritici was placed on top of the vermiculite. Each tube was immediately watered with $10 \mathrm{ml}$ of tap water amended with metalaxyl (Ridomil 0.075 g/liter; Ciba Geigy Corp., Greensboro, NC) to inhibit indigenous Pythium species. Tubes were preincubated 7 days before planting in tests with Rhizoctonia root rot and 2 days in tests with take-all. For both kinds of tests, two wheat seeds were placed on the soil surface in each tube and covered with another 2-cm-thick layer of sterile vermiculite. After sowing, each tube received an additional $5 \mathrm{ml}$ of tap water, and the racks of tubes were then returned to a growth chamber with a 12 -h photoperiod and a constant $15^{\circ} \mathrm{C}$. For the first week, each tube received $5 \mathrm{ml}$ of tap water twice (days 3 or 4 and 6 or 7 after planting and, thereafter, $5 \mathrm{ml}$ of $1 / 3-(\mathrm{vol} / \mathrm{vol})$ strength Hoagland's solution twice per week. After 3 to 4 weeks, roots of wheat seedlings were washed free of the rooting medium, and disease was evaluated. Emergence and shoot length (measured on washed seedlings from the position of the remnant seed piece to the tip of the longest leaf) was determined for each test.

Severity of Rhizoctonia root rot was evaluated on a scale of 0 to 8 in which $0=$ no lesion evident, $1=<50 \%$ roots with a single typical brown sunken lesion, $2=<50 \%$ roots each having a few lesions, $3=>50 \%$ roots each with one or more lesions, $4=<50 \%$ roots with lesions within $1 \mathrm{~cm}$ from the seed, $5=>50 \%$ roots with brown sunken lesions within $1 \mathrm{~cm}$ from the seed, $6=>50 \%$ roots shorter than $3 \mathrm{~cm}$ (inoculum line) from the seed, $7=>50 \%$ roots shorter than $1 \mathrm{~cm}$ from the seed, and $8=$ almost no roots with stunting or death of seedling. Severity of take-all was evaluated on the 0 to 8 scale developed by Ownley et al. (31).

Tests with Pythium root rot used 9.5-cm-diameter pots filled with $200 \mathrm{cc}$ of sterile vermiculite followed by $300 \mathrm{~g}$ of soil naturally infested with Pythium species (10). Prior to planting, each pot received $100 \mathrm{ml}$ of tap water and was incubated for 2 days at room temperature. Seven seeds were sown about $2 \mathrm{~cm}$ deep in each pot and covered with $100 \mathrm{cc}$ of vermiculite. Each pot received $50 \mathrm{ml}$ of tap water and then was incubated at $15^{\circ} \mathrm{C}$ for 4 weeks in a growth chamber. Each pot received $50 \mathrm{ml}$ of dilute $(1 / 3, \mathrm{vol} / \mathrm{vol})$ Hoagland's solution once each week. Emergence, shoot height, and length of the first true leaf of wheat seedlings (16) were recorded.

All experiments were conducted with Thatuna silt loam obtained from a plot cropped every second or third year to wheat on the Washington State University (WSU) Plant Pathology Research Farm, Pullman (32). The soil was collected from the top 10- to 15$\mathrm{cm}$ layer of the soil profile and passed through a $0.5-\mathrm{cm}-\mathrm{mesh}$ screen. Steamed soil refers to moist soil that was treated at $95^{\circ} \mathrm{C}$ for 30 min using air mixed with steam. Raw soil refers to the same soil without heat treatment. Soils were prepared 1 week prior to each experiment and air-dried at room temperature on a bench in the greenhouse.
In all experiments, treatments were arranged in a randomized complete block with five replicates of steamed and raw soils. Effect of all seed treatments was analyzed by the SAS general linear model procedure (SAS Institute, Cary, NC), and treatment means were separated by Fisher's protected least significant difference (LSD) at $P=0.05$.

Field studies. Studies were conducted with spring wheat and spring barley planted 9 April 1993 on a farm near Dusty, WA, and with spring wheat planted 15 April 1993 on the WSU Plant Pathology Research Farm, Pullman. At Dusty, two adjacent sites were used in the same field; one had been planted to spring wheat and the other to spring barley in the previous year. These two tests relied entirely on natural inoculum of the three kinds of wheat root pathogens. At the site on the WSU Plant Pathology Research Farm, oat-kernel inoculum of $R$. solani AG8 was added to the soil and sown to barley the previous fall. The barley in a vegetative stage was cut with a mower, and the soil surface was disked the following spring 2 weeks before planting spring wheat. Studies were also conducted with spring wheat planted 8 April 1994 near Dusty, winter wheat planted 19 October 1993 near Almota, WA, and winter wheat planted 30 October 1993 at the WSU Plant Pathology Research Farm (a different field than used in 1993). All three sites where tests were done in 1994 had been planted to wheat frequently in previous years and, therefore, provided natural soil infestations of wheat root pathogens.

Treatments were arranged in a randomized complete block design with each treatment replicated five times. Unless stated otherwise, each treatment consisted of eight 8-m-long rows uniformly spaced at $30 \mathrm{~cm}$ apart. Seedling emergence was estimated on the basis of subjective visual assessments of stand establishment scored independently by three people to the nearest $10 \%$. At the beginning of the assessment, a plot with high density of emerged seedlings was given a rating of $90 \%$ and, thereafter, other plots were scored within the range of 0 to $100 \%$. Root disease severity

TABLE 1. Effect of seed treatment with Bacillus strains on suppression of Rhizoctonia root rot caused by Rhizoctonia solani AG8 and take-all caused by Gaeumannomyces graminis var. tritici in growth chamber assays

\begin{tabular}{|c|c|c|c|}
\hline Seed treatment ${ }^{\mathrm{u}}$ & Emergence (\%) & $\begin{array}{l}\text { Shoot height }{ }^{v} \\
(\mathrm{~cm})\end{array}$ & $\begin{array}{l}\text { Disease }^{\mathrm{w}} \\
\text { severity }\end{array}$ \\
\hline \multicolumn{4}{|c|}{ Rhizoctonia root $\operatorname{rot}^{x}$} \\
\hline Nontreated & $91.0 \mathrm{AB}^{\mathrm{y}}$ & $20.2 \mathrm{~A}$ & $4.69 \mathrm{~A}$ \\
\hline Methylcellulose & $87.9 \mathrm{AB}$ & $20.8 \mathrm{~A}$ & $4.50 \mathrm{~A}$ \\
\hline L324-92 & $92.0 \mathrm{~A}$ & $21.2 \mathrm{~A}$ & $3.62 \mathrm{~B}$ \\
\hline L331-92 & $84.0 \mathrm{~B}$ & $18.9 \mathrm{~A}$ & $3.55 \mathrm{~B}$ \\
\hline P206-92 & $84.0 \mathrm{~B}$ & $20.0 \mathrm{~A}$ & $3.60 \mathrm{~B}$ \\
\hline \multicolumn{4}{|l|}{ Take-all $^{\mathrm{z}}$} \\
\hline Nontreated & $92.0 \mathrm{~A}$ & $20.1 \mathrm{~A}$ & $3.92 \mathrm{~A}$ \\
\hline Methylcellulose & $95.0 \mathrm{~A}$ & $19.7 \mathrm{~A}$ & $3.69 \mathrm{~A}$ \\
\hline L324-92 & $89.0 \mathrm{~A}$ & $20.2 \mathrm{~A}$ & $2.80 \mathrm{C}$ \\
\hline L331-92 & $93.0 \mathrm{~A}$ & $19.6 \mathrm{~A}$ & $3.13 \mathrm{~B}$ \\
\hline P206-92 & $96.0 \mathrm{~A}$ & $19.6 \mathrm{~A}$ & $2.76 \mathrm{C}$ \\
\hline
\end{tabular}

u Ten grams of wheat seed was coated with $4 \mathrm{ml}$ of a $0.5 \%$ methylcellulose suspension mixed with cells of the respective strains grown on nutrient broth-yeast extract agar for $48 \mathrm{~h}$ at 21 to $24^{\circ} \mathrm{C}$. Initial populations of $\mathrm{Ba}$ cillus strains were 7.2, 7.4, and 7.4 log CFU/seed for L324-92, L331-92, and P206-92, respectively.

v Shoot heights were measured 21 days after planting.

${ }^{w}$ Severity of Rhizoctonia root rot was evaluated on a scale ranging from 0 (= no lesion evident) to 8 (= almost no roots with stunting or death of seedling); severity of take-all was evaluated on a scale from 0 (= no disease evident) to 8 (= plant dead or nearly so).

${ }^{x}$ For Rhizoctonia root rot, one whole oat kernel colonized with $R$. solani AG8 was added to Thatuna silt loam.

y Means with the same letter in the same column within the same experiment are not significantly different at $P=0.05$ according to Fisher's protected least significant difference. Treatment means were analyzed using data pooled from raw and steamed soils, because of no interaction between soil and seed treatment.

${ }^{\mathrm{z}}$ For take-all, soil was infested with $1 \%$ oat-kernel inoculum of G. graminis var. tritici. 
was rated during the vegetative stages of plant growth for Rhizoctonia root rot and take-all using the 0 to 8 scale described above. Yields were obtained by harvesting the five center rows out of each eight-row plot, leaving one border row on one side and two border rows on the other side of each harvested plot. Effect of the seed treatment was analyzed by the SAS general linear model procedure. Treatment means were compared statistically by the SAS general linear models procedures and means were compared by Fisher's protected LSD test at $P=0.05$.

Both seeds and fertilizers were placed as a "one-pass" operation directly into stubble ("no-till") of the previous crop (8). The drill was equipped with fertilizer shanks to both loosen the soil in the seed furrow and place nitrogen, phosphate, and sulfate 6 to $8 \mathrm{~cm}$ beneath the seed. Seeding rates were $90 \mathrm{~kg} / \mathrm{ha}$ for both spring and winter wheat. Cultivar Penawawa was used as the spring wheat and 'Madsen' as the winter wheat in all field studies. The bacterial doses ranged from $10^{6}$ to $10^{7} \mathrm{CFU} /$ seed for Bacillus strains, depending on the field test, and was about $10^{8} \mathrm{CFU} / \mathrm{seed}$ for $\mathrm{Pseu}$ domonas fluorescens-putida Q69c-80. Fertilizer rates were based on a soil test, and a predetermined yield goal was established on the basis of estimated available water (11). Control plots included nontreated seed and seed treated with a $1.5 \%$ methylcellulose suspension sown into raw soil and nontreated seed sown into plots fumigated with methyl bromide at a rate of $50 \mathrm{~g} / \mathrm{m}^{2}$ applied under 6-mm plastic tarp just before planting.

The commercially available chemicals tested as seed treatments were metalaxyl (Apron), $10.6 \mathrm{mg}$ a.i./kg of seed; pentachloronitrobenzene (PCNB), $52 \mathrm{mg}$ a.i./kg of seed; and difenoconazole (Dividend), $120 \mathrm{mg}$ a.i./kg of seed.

\section{RESULTS}

Isolation of wheat root-associated, heat-resistant bacteria. As expected, heat treatment greatly reduced the number of bacteria recovered from the macerated roots as compared with those recovered from roots before the heat treatment. For example, population densities on roots of wheat seedlings from the Lind site were approximately $3.0 \times 10^{7}$ and $3.6 \times 10^{3} \mathrm{CFU} / \mathrm{cm}$ of roots before and after the heat treatment, respectively. Bacterial populations after four washings followed by the heat treatment of the washed roots were $31 \mathrm{CFU} / \mathrm{cm}$ of root, which was $0.9 \%$ of populations obtained after one washing followed by the heat treatment.

Of approximately 2,000 original bacterial isolates, 310 isolates showed inhibition to $R$. solani AG8 on $1 / 10$ TSA, and all of these also inhibited $G$. graminis var. tritici at $15^{\circ} \mathrm{C}$ on $1 / 5$ PDA. Of the 310 isolates, $172(55.5 \%)$ were inhibitory to Pythium.

Performance of bacterial isolates in the growth chamber assay. Of 310 isolates initially screened for ability to suppress Rhizoctonia root rot in the tube assay, three strains, L324-92, L331-92, and P206-92, were significantly more suppressive to Rhizoctonia root rot and take-all as compared with the nontreated control and methylcellulose treatment (Table 1). In tests against Pythium root rot, only L324-92 significantly $(P=0.05)$ increased wheat seedling emergence $(38.9 \%)$ and length of the first true leaf $(30.5 \%)$ over the nontreated control (Fig. 1). Neither of the other two strains exhibited any activity against Pythium root rot, based on either seedling emergence or length of the first true leaf.

Performance in field trials. At the Dusty site in 1993, the emergence of spring wheat in the plots with spring wheat as the previous crop was $76 \%$ with soil fumigation, $74 \%$ in response to L324-92, and $62 \%$ with no soil fumigation or seed treatment (Table 2). L324-92 significantly increased yield (22.5\%) as compared with the nontreated control; the yield in response to L32492 was not different from that in response to soil fumigation or difenoconazole seed treatment.

In the plots where spring barley was the previous crop, L324-92, Q69c-80, and soil fumigation increased yield 24.8, 29.6, and $26.0 \%$, respectively, as compared with the nontreated control. All three treatments were significantly better than difenoconazole, but were not different among themselves.

In 1993 at the WSU Plant Pathology Research Farm, emergence of wheat treated with L324-92 was $80 \%$ as compared with $63 \%$ for the nontreated control. L324-92 also resulted in less Rhizoctonia root rot in this test (Table 2). Strains L331-92 and P206-92 had

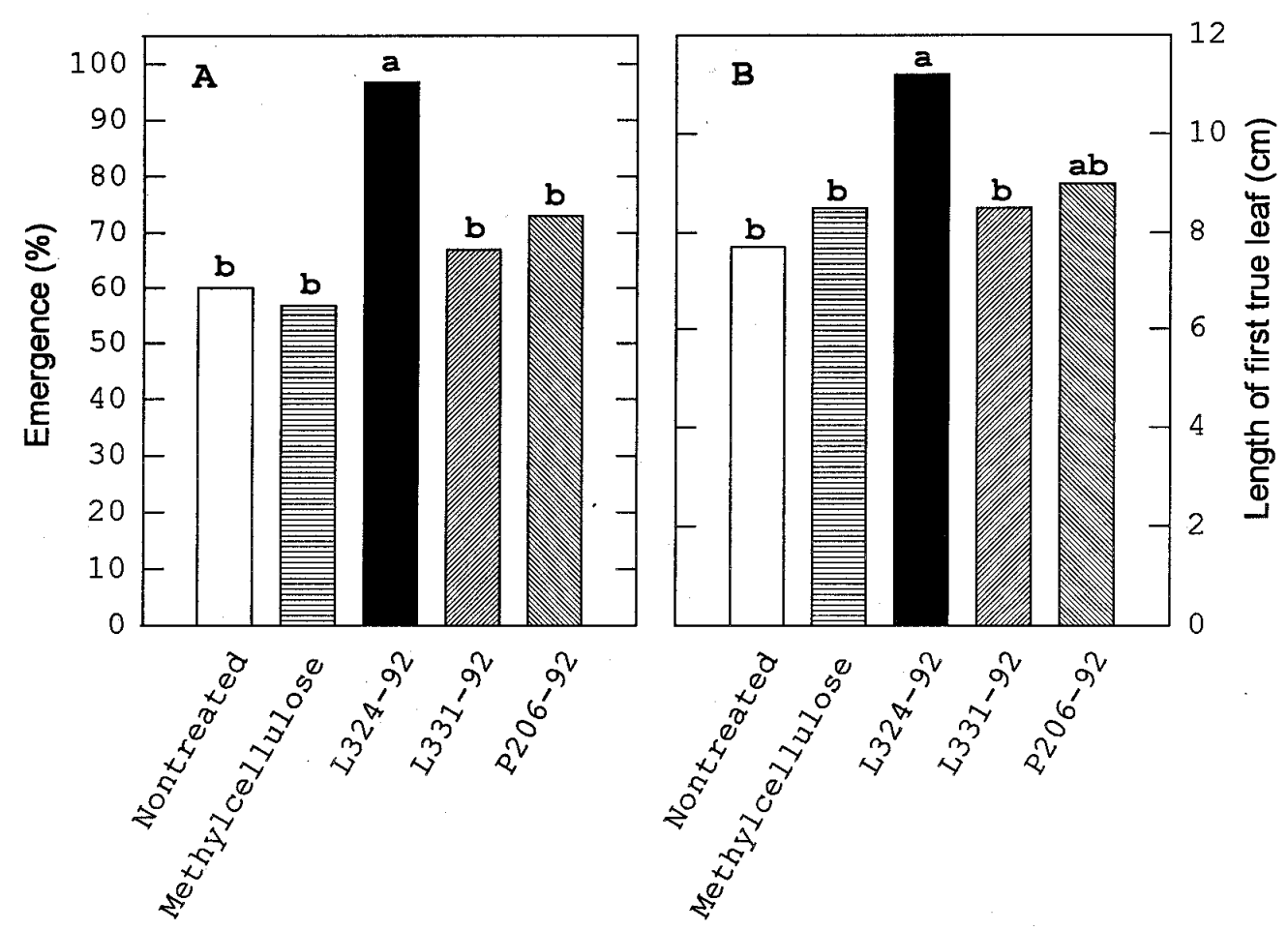

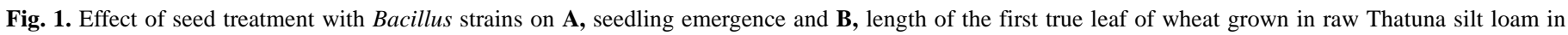

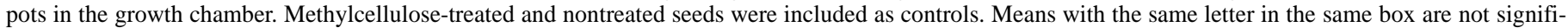
cantly different at $P=0.05$ according to Fisher's protected least significant difference. 
no effect on emergence, but both suppressed Rhizoctonia root rot compared with the methylcellulose treatment. Serious damage by Hessian fly destroyed the experiment before harvest.

In 1994 at Dusty, L324-92 and Q69c-80 resulted in significantly $(P=0.05)$ less take-all than the nontreated control, but had no significant effect on Rhizoctonia root rot. Soil fumigation was the only treatment in this test that significantly increased yield. Neither L324-92 nor Q69c-80 provided significant control of Rhizoctonia root rot on the winter wheat planted directly into spring wheat stubble near Almota, whereas fumigation with methyl bromide resulted in significantly less Rhizoctonia root rot (Table 2). Take-all was generally too mild at this site to distinguish treatment effects. The plot was not harvested for yield because of dense carryover of volunteer spring wheat.

In vitro inhibition of root pathogens by Bacillus sp. L324-92. L324-92 inhibited growth of all fungal isolates tested on $1 / 5$ PDA at $15^{\circ} \mathrm{C}$ (Table 3). For isolates of either G. graminis var. tritici or $R$. solani, sensitivity of each fungus to L324-92 did not vary much between species, but did vary among isolates of the same species. For Pythium species, the sensitivity varied greatly among species; $P$. volvotum was most sensitive and $P$. sylvaticum was least sensitive to L324-92.
Influence of temperature on growth of Bacillus sp. L324-92. Bacillus sp. L324-92 grew better than B. subtilis A13 at 15 and $20^{\circ} \mathrm{C}$ (Fig. 2). L324-92 grew at $10^{\circ} \mathrm{C}$, but A13 did not grow at $10^{\circ} \mathrm{C}$. L324-92 also grew at temperatures as low as $4^{\circ} \mathrm{C}$, with doubling time of $55.2 \mathrm{~h}$ between 7 and 14 days after inoculation in $25 \mathrm{ml}$ of NBY broth.

Identification of strains L324-92, L331-92, and P206-92. Strains L324-92, L331-92, and P206-92 are straight rod-shaped, strictly aerobic, catalase-positive, endospore-forming bacteria. Strain L324-92 is Gram-variable, whereas L331-92 and P206 are Gram-positive. After 5 days of incubation on $1 / 10$ TSA at $27^{\circ} \mathrm{C}$, the colonies of L324-92 remained milky white and those of L331-92 and P206-92 were dark brown. Using the API CHB 50 system, strains L331-92 and P206-92 were identified as B. subtilis, but L324-92 could not be identified (data not shown). On the basis of whole-cell fatty acid analysis conducted by Microbial ID, Inc., strains L331-92 and P206-92 were confirmed as B. subtilis. Strain L324-92 did not match with any known Bacillus species, but was closest to B. maroccanus (data not shown). On the basis of standard biochemical and physiological tests conducted by the American Type Culture Collection, L324-92 did not match with any known species, but was closest to B. badius. L324-92 differed

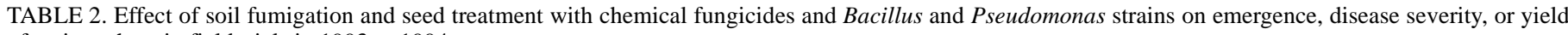
of spring wheat in field trials in 1993 to 1994

\begin{tabular}{|c|c|c|c|c|c|c|}
\hline Year and site & Previous crop & Seed (or soil) treatment & Emergence $^{\mathrm{m}}(\%)$ & Take-all $^{\mathrm{n}}$ & Rhizoctonia root $\operatorname{rot}^{\circ}$ & Yield (kg/ha) \\
\hline \multicolumn{7}{|l|}{1993} \\
\hline \multirow[t]{5}{*}{ Dusty } & Spring wheat ${ }^{\mathrm{p}}$ & Nontreated & $62 \mathrm{~B}^{\mathrm{q}}$ & & & $2,613.0 \mathrm{~B}$ \\
\hline & & Methylcellulose $\mathrm{r}^{\mathrm{r}}$ & $58 \mathrm{~B}$ & & & $2,561.0 \mathrm{~B}$ \\
\hline & & Difenoconazole $\mathrm{s}$ & $46 \mathrm{C}$ & & & $3,150.0 \mathrm{~A}$ \\
\hline & & Fumigated ${ }^{\mathrm{t}}$ & $76 \mathrm{~A}$ & & & $3,614.0 \mathrm{~A}$ \\
\hline & & L324-92u & $74 \mathrm{~A}$ & & & $3,201.5 \mathrm{~A}$ \\
\hline \multirow[t]{6}{*}{ Dusty } & Spring barley ${ }^{\mathrm{v}}$ & Nontreated & & & & $2,311.4 \mathrm{~B}$ \\
\hline & & Difenoconazole & & & & $2,342.0 \mathrm{~B}$ \\
\hline & & Fumigated & & & & $2,913.4 \mathrm{~A}$ \\
\hline & & L324-92 & & & & $2,866.8 \mathrm{~A}$ \\
\hline & & $\mathrm{P} 206-92^{\mathrm{w}}$ & & & & $2,229.4 \mathrm{~B}$ \\
\hline & & Q69c-80x & & & & $2,996.6 \mathrm{~A}$ \\
\hline \multirow[t]{5}{*}{ Pullman } & Spring wheat & Nontreated & $63 \mathrm{C}$ & & $2.51 \mathrm{AB}$ & \\
\hline & & Methylcellulose & $75 \mathrm{AB}$ & & $3.13 \mathrm{~A}$ & \\
\hline & & L324-92 & $80 \mathrm{~A}$ & & $1.63 \mathrm{D}$ & \\
\hline & & L331-92y & $65 \mathrm{BC}$ & & $1.90 \mathrm{BCD}$ & \\
\hline & & P206-92 & $64 \mathrm{BC}$ & & $2.29 \mathrm{BC}$ & \\
\hline \multicolumn{7}{|l|}{1994} \\
\hline \multirow[t]{7}{*}{ Dusty } & Spring wheat & Nontreated & & $3.84 \mathrm{~A}$ & $6.20 \mathrm{AB}$ & $1,573.3 \mathrm{~B}$ \\
\hline & & Methylcellulose & & & & $1,558.2 \mathrm{~B}$ \\
\hline & & Fumigated & & $0.39 \mathrm{C}$ & $1.41 \mathrm{C}$ & $2,062.8 \mathrm{~A}$ \\
\hline & & Apron/PCNB ${ }^{z}$ & & $2.44 \mathrm{~B}$ & $5.67 \mathrm{~B}$ & $1,356.7 \mathrm{~B}$ \\
\hline & & Difenoconazole & & $2.86 \mathrm{AB}$ & $6.34 \mathrm{AB}$ & $1,212.5 \mathrm{~B}$ \\
\hline & & L324-92 & & $2.38 \mathrm{~B}$ & $5.22 \mathrm{~B}$ & $1,247.0 \mathrm{~B}$ \\
\hline & & Q69c-80 & & $2.29 \mathrm{~B}$ & $4.97 \mathrm{~B}$ & $1,486.5 \mathrm{~B}$ \\
\hline \multirow[t]{4}{*}{ Almota } & Winter wheat & Nontreated & & $0.37 \mathrm{AB}$ & $3.46 \mathrm{~A}$ & \\
\hline & & Fumigated & & $0.04 \mathrm{~B}$ & $1.64 \mathrm{~B}$ & \\
\hline & & L324-92 & & $0.29 \mathrm{AB}$ & $3.37 \mathrm{AB}$ & \\
\hline & & Q69c-80 & & $0.85 \mathrm{~A}$ & $2.66 \mathrm{~A}$ & \\
\hline
\end{tabular}

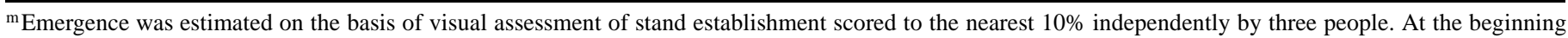
of the assessment, a plot with high density was given a rating of $90 \%$, thereafter other plots were scored with the range of 0 to $100 \%$.

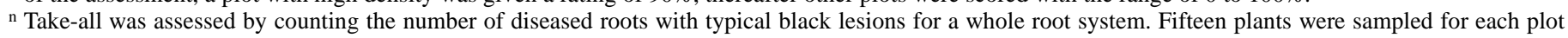
with five replicates at the flowering stage.

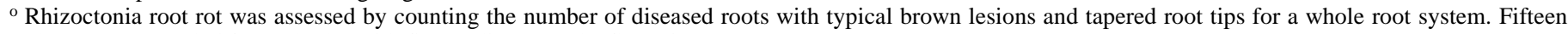
plants were sampled for each plot with five replicates at the flowering stage.

p Seed of wheat was sown in March directly into the standing stubble of the previous year's spring wheat.

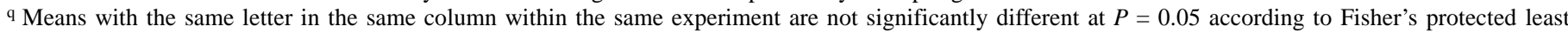
significant difference.

${ }^{\mathrm{r}}$ Seed treated with $1.5 \%$ methylcellulose.

s Seed treated with difenoconazole, which is 1-\{2-[4-(4-chlorophenoxy)-2-chlorophenyl-(4-methyl-1,3-dioxolan-2-yl)-methyl]\}-1H-1,2,4-triazole.

${ }^{t}$ Plot was fumigated with methyl bromide at $50 \mathrm{~g} / \mathrm{m}^{2}$ applied under clean plastic tarp.

u Seed treated with Bacillus sp. L324-92 at a dose of $6.3 \log$ CFU/seed.

v Spring wheat was sown in March directly into the standing stubble of the previous year's spring barley.

${ }^{w}$ Seed treated with cells of B. subtilis P206-92 at a dose of 6.7 log CFU/seed.

x Seed treated with cells of Pseudomonas fluorescens-putida Q69c-80 at a dose of $7.8 \log$ CFU/seed.

y Seed treated with cells of B. subtilis L331-92 at a dose of 6.5 log CFU/seed.

${ }^{\mathrm{z}}$ Seed treated with both metalaxyl and pentachloronitrobenzene. 
from $B$. badius in that it was positive for citrate utilization, esculin decomposition, and nitrate reduction, and it grew maximally at $40^{\circ} \mathrm{C}$ compared with $50^{\circ} \mathrm{C}$ for $B$. badius.

\section{DISCUSSION}

We report the existence of a unique and apparently undescribed Bacillus sp. with biocontrol activity against three major wheat root diseases. This strain was isolated in 1992 from washed roots of wheat obtained from a field plot near Lind, WA, where wheat had been grown in rotation with fallow for some 60 years and then annually with irrigation since 1967. Take-all occurred and was severe at the site during the first 10 years of continuous irrigated wheat, but then declined as the soil became suppressive to this disease (11). Pseudomonas fluorescens 2-79, a biocontrol agent to take-all, was isolated from this same site in 1979 (45). L324-92 is inhibitory in vitro at $15^{\circ} \mathrm{C}$ against all tested isolates of $G$. graminis var. tritici, species and anastomosis groups of Rhizoctonia, and species of Pythium. It also grows at temperature as low as $4^{\circ} \mathrm{C}$, which is uncommon for Bacillus species. L324-92 could not be identified at the species level by the API CHB 50 system, Microbial ID, Inc., or the American Type Culture Collection.

The approach used to isolate L324-92 followed the protocols used to isolate fluorescent pseudomonads as candidate biocontrol agents (48), but with three differences: (i) macerates of washed roots rather than root washings were dilution-plated as a source of microorganisms, (ii) roots selected for serial dilutions were heattreated at $80^{\circ} \mathrm{C}$ for $30 \mathrm{~min}$ so as to select only endospore-forming bacteria, and (iii) candidate isolates were screened against all three target pathogens. The root-enrichment approach works on the basic principle that the chances of finding soil microorganisms

TABLE 3. Spectrum of in vitro inhibitory activity of Bacillus sp. L324-92 against fungal root pathogens ${ }^{\mathrm{x}}$

\begin{tabular}{|c|c|c|c|c|}
\hline Genus & Species & Subgroup & $\mathrm{A} / \mathrm{B}^{\mathrm{y}}$ & $\begin{array}{c}\% \\
\text { inhibition }^{\mathrm{z}}\end{array}$ \\
\hline Gaeumannomyces & graminis & tritici & $36 / 36$ & 61 \\
\hline \multirow[t]{11}{*}{ Rhizoctonia } & solani & AG1 & $2 / 2$ & 45 \\
\hline & & AG2-1 & $3 / 3$ & 50 \\
\hline & & AG2-2 & $3 / 3$ & 47 \\
\hline & & AG3 & $3 / 3$ & 55 \\
\hline & & AG4 & $2 / 12$ & 52 \\
\hline & & AG5 & $3 / 3$ & 46 \\
\hline & & AG6 & $3 / 3$ & 53 \\
\hline & & AG8 & $12 / 12$ & 58 \\
\hline & oryzae & AG-D & $1 / 1$ & 55 \\
\hline & & AG-E & $1 / 1$ & 56 \\
\hline & & WACO & $3 / 3$ & 72 \\
\hline \multirow[t]{12}{*}{ Pythium } & irregulare & & $1 / 1$ & 33 \\
\hline & ultimum & ultimum & $1 / 1$ & 38 \\
\hline & ultimum & sporangiiferum & $2 / 2$ & 33 \\
\hline & aristosporum & & $1 / 1$ & 30 \\
\hline & gramineum & & $1 / 1$ & 25 \\
\hline & heterothallicum & & $1 / 1$ & 35 \\
\hline & intermedium & & $1 / 1$ & 50 \\
\hline & macrosperma & & $1 / 1$ & 38 \\
\hline & rostratum & & $1 / 1$ & 42 \\
\hline & sylvaticum & & $1 / 1$ & 88 \\
\hline & torulosum & & $1 / 1$ & 30 \\
\hline & volvotum & & $1 / 1$ & 47 \\
\hline
\end{tabular}

${ }^{x}$ A $10-\mu$ l aliquot of strain L324-92 was spotted at the opposite edges of $1 / 5$ potato dextrose agar plates, and the plates were incubated at $15^{\circ} \mathrm{C}$. After 2 days, one disc ( $8 \mathrm{~mm}$ diameter) of one of the fungal isolates was placed in the center of each dish, and then the plates were incubated further at $15^{\circ} \mathrm{C}$ for 1 week.

${ }^{\text {y }} \mathrm{A}=$ number of fungal isolates inhibited by Bacillus sp. L324-92; B = number of isolates tested.

${ }^{\mathrm{z}}$ The values represent the radius of the fungal colony in the direction of the bacterial colonies divided by radius of the fungal colony in the direction with no bacterial colonies. Each value is the pooled mean of all isolates tested. Mean for each isolate was estimated with two measurements from each of five plates. adapted to a specific substrate or habitat are increased by repeatedly exposing the soil microbiota to that substrate or habitat successively to enrich for the desired types (5). It is noteworthy that many Bacillus isolates can be easily obtained after harsh repeated washings of the roots followed by heat treatment.

The problem of disease replacement, whereby one root disease is controlled but another takes its place (6), and the evidence that antibiosis is an important mechanism of biological control of wheat root pathogens $(44,47)$ led to the decision to screen all isolates for in vitro antibiosis against representative isolates of all three groups of root pathogens important in the root disease complex on direct-drilled wheat in the Inland Northwest. Ability to inhibit $R$. solani AG8 in vitro and suppress Rhizoctonia root rot was the first screen, followed by in vitro screens for ability of those inhibitory to $R$. solani AG8 to also inhibit $G$. graminis var. tritici and $P$. irregulare. Strain L324-92 was the only strain remaining after the final in vivo screens against take-all and Pythium root rot. This more extensive protocol involving both in vitro and in vivo screening against each of these three very different root pathogens possibly accounts for the recovery of the broad-spectrum biocontrol agent L324-92. Similarly, Broadbent et al. (2) screened for in vitro inhibitory activity against nine test pathogens to recover $B$. subtilis A13, which is also known for its broad-spectrum activity.

Bacillus sp. L324-92 significantly increased yields of spring wheat direct-drilled into standing stubble of spring wheat and spring barley (separate field experiments) in 1993 in which all three root diseases occurred as a mixture. Yields in these two experiments were not significantly different from those in plots fumigated with methyl bromide and, on the spring barley site, yields were significantly higher in response to the two bacteria than in response to a difenoconazole seed treatment. Strain L324-92 also significantly suppressed take-all, but only soil fumigation with methyl bromide reduced the severity of Rhizoctonia root rot in the spring wheat field trial conducted near Dusty, WA, in 1994. The failure of the seed treatments to control Rhizoctonia root rot may explain the uniformly low yields and lack of any yield responses other than to methyl bromide in this field trial. Neither strain provided significant control of either root disease on winter wheat direct-drilled into the same spring wheat stubble near Almota in the 1993 to 1994 crop year. Since these studies, treatment of seed with L324-92 resulted in significantly less take-all on both seminal and crown roots of winter wheat direct-drilled into spring

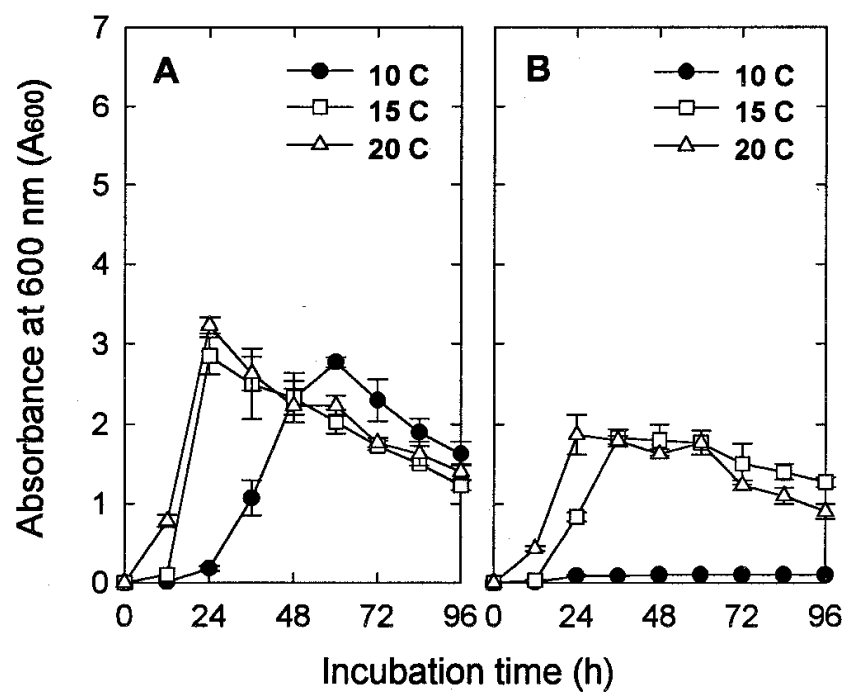

Fig. 2. Influence of temperature on growth of A, Bacillus sp. L324-92 and B, B. subtilis A13 in nutrient broth-yeast extract (NBY) medium. Each strain was grown in $50 \mathrm{ml}$ of NBY in 250-ml Erlenmeyer flasks at $150 \mathrm{rpm}$ on a rotary shaker; growth was measured spectrophotometrically at $600 \mathrm{~nm}$. The vertical bars represent standard deviations with three replicates. 
wheat stubble and less Rhizoctonia root rot on spring wheat direct-drilled into spring wheat stubble in tests conducted on this same farm, but in a different field, in 1996 (R. J. Cook, D. M. Weller, and M. Mezzalama, unpublished data).

Several studies have shown the potential for Bacillus species to control damping-off and improve stand establishment of a diversity of crops $(2,14,18,22,28)$. Wheat rarely damps off, except when the seed is old (15); more commonly, infections by Pythium and Rhizoctonia species affect seedling vigor and this, in turn, can limit tillering and yield. Part of the increased yield of wheat grown from seed treated with L324-92 was likely the result of greater seedling vigor in response to this microorganism. This was particularly obvious in the spring wheat planted into the stubble of either spring wheat or spring barley in the field near Dusty in 1993. Take-all, on the other hand, begins on young plants, but develops slowly and throughout the life of the plant. Our results show that strain L324-92 is also a potential biocontrol agent of this disease in addition to Pythium and Rhizoctonia root rots.

No attempt was made to deliberately screen for strains with ability to grow at low temperatures. It is, therefore, fortuitous that the one strain selected out of the approximately 2,000 screened for activity against all three root diseases can grow at temperatures as low as $4^{\circ} \mathrm{C}$. Ability to grow at low temperatures would greatly favor ability to compete with the many other potential colonists of wheat roots at the Lind site, in which case, simply limiting the screen to those strains present on or within roots after four consecutive washes would have greatly increased the chances of finding a low-temperature strain. Having screened rhizobacteria from roots of wheat seedlings taken from the field in the fall when temperatures were generally low could also have increased the chances of finding a low-temperature strain. According to Sneath (40), only four Bacillus species out of 34 species can grow below $5^{\circ} \mathrm{C}$; these are $B$. globisporus, $B$. insolitus, B. macquariensis, and $B$. marinus. However, these species do not grow at temperatures above $30^{\circ} \mathrm{C}$, whereas Bacillus sp. L324-92 can grow at temperatures up to $40^{\circ} \mathrm{C}$. Apparently, L324-92 is adapted to a broad range of temperatures and not just the local soil environment of the Inland Northwest.

Discovery of L324-92 suggests that the possibility of finding Bacillus species as biocontrol agents can be enhanced using a protocol designed to isolate root-associated, endospore-forming bacteria exclusively and then screening candidate strains against the species of the pathogens likely to cause root diseases on the same plant. Isolation of Bacillus sp. L324-92 with broad-spectrum inhibitory activity against wheat root pathogens and ability to grow at low temperatures favorable to these pathogens also supports the hypothesis that natural biocontrol strains with desired characteristics and adapted to specific ecological habitats can be obtained by enrichment procedures using the host-pathogen interaction for the enrichment.

Strain L324-92 is one of several antibiotic-producing bacteria obtained from the rhizosphere of wheat grown in take-all decline soil and shown to suppress take-all when introduced as a seed inoculation. Others include Pseudomonas fluorescens 2-79, which suppresses take-all by production of phenazine-1-carboxylate (41); Pseudomonas aureofaciens 30-84, which suppresses by production of three phenazine antibiotics (33); and Pseudomonas fluorescens Q2-87, which produces 2,4-diacetylphloroglucinol (43). Pseudomonas fluorescens-putida Q69c was also isolated from a take-all decline soil and is suppressive to take-all (32), but produces no detectable antibiotic or inhibition of G. graminis var. tritici in vitro. Whether any one or a combination of these diseasesuppressive mechanisms accounts for take-all decline remains unknown. Nevertheless, the discovery of these strains, most recently a Bacillus sp., confirms the notion that the rhizosphere of wheat in take-all decline soil is a fertile hunting place for effective biocontrol strains not only for use against take-all, but possibly for use against an entire root disease complex.

\section{LITERATURE CITED}

1. Baker, K. F., and Cook, R. J. 1974. Biological Control of Plant Pathogens. W. H. Freeman and Co., San Francisco.

2. Broadbent, P., Baker, K. F., and Waterworth, Y. 1971. Bacteria and actinomycetes antagonistic to fungal root pathogens in Australian soil. Aust. J. Biol. Sci. 24:925-944.

3. Campbell, R., and Faul, J. L. 1979. Biological control of Gaeumannomyces graminis: Field trials and the ultrastructure of the interaction between the fungus and a successful antagonistic bacterium. Pages 603609 in: Soil-borne Plant Pathogens. B. Schippers and W. Gams, eds. Academic Press, London.

4. Chamswarng, C., and Cook, R. J. 1985. Identification and comparative pathogenicity of Pythium species from wheat roots and wheat-field soils in the Pacific Northwest. Phytopathology 75:821-827.

5. Cook, R. J. 1991. Biological control of plant diseases: Broad concepts and applications. Food Fert. Technol. Cent. Tech. Bull. 123:1-29.

6. Cook, R. J. 1992. Wheat root heath management and environmental concern. Can. J. Plant Pathol. 14:76-85.

7. Cook, R. J. 1992. A customized approach to biological control of wheat root diseases. Pages 211-222 in: Biological Control of Plant Diseases: Progress and Challenges for the Future. E. C. Tjamos, G. C. Papavizas, and R. J. Cook, eds. Plenum Press, New York.

8. Cook, R. J. 1994. Problems and progress in biological control of take-all. Plant Pathol. 43:429-437.

9. Cook, R. J., and Haglund, W. A. 1991. Wheat yield depression associated with conservation tillage caused by root pathogens in the soil not phytotoxins from the straw. Soil Biol. Biochem. 23:1125-1132.

10. Cook, R. J., Sitton, J. W., and Haglund, W. A. 1987. Influence of soil treatments on growth and yield of wheat and implications for control of Pythium root rot. Phytopathology 77:1192-1198.

11. Cook, R. J., and Veseth, R. J. 1991. Wheat Health Management. The American Phytopathological Society, St. Paul, MN.

12. Cook, R. J., Brucart, W. L., Coulson, J. R., Goettel, M. S., Humber, R. A., Lumsden, R. D., Maddox, J. V., McManus, M. L., Moore, L., Meyer, S. F., Quimby, P. C., Stack, J. P., and Vaughn, J. L. 1996. Safety of microorganisms intended for pest and plant disease control: Framework for scientific evaluation. Biol. Control 7:333-351.

13. Halverson, L. J., Clayton, M. K., and Handelsman, J. 1993. Population biology of Bacillus cereus UW85 in the rhizosphere of field-grown soybeans. Soil Biol. Biochem. 25:485-493.

14. Handelsman, J., Raffel, S., Mester, E. H., Wunderlich, L., and Grau, C. R. 1990. Biological control of damping-off of alfalfa seedlings with $\mathrm{Ba}$ cillus cereus UW85. Appl. Environ. Microbiol. 56:713-718.

15. Hering, T. F., Cook, R. J., and Tang, W.-h. 1987. Infection of wheat embryos by Pythium species during seed germination and the influence of seed age and soil matric potential. Phytopathology 77:1104-1108.

16. Ingram, D. M., and Cook, R. J. 1987. Pathogenicity of four Pythium species to wheat, barley, peas and lentils. Plant Pathol. 39:110-117.

17. King, E. O., Ward, M. K., and Raney, D. E. 1954. Two simple media for the demonstration of pyocyanin and fluorescein. J. Lab. Clin. Med. 44:301-307.

18. Liu, Z. L., and Sinclair, J. B. 1991. Effect of seed coating with Bacillus spp. on Rhizoctonia damping-off, root and stem rot of soybeans, 1990. Biol. Cult. Tests Control Plant Dis. 6:62.

19. Liu, Z. L., and Sinclair, J. B. 1992. Population dynamics of Bacillus megaterium strain B153-2-2 in the rhizosphere of soybean. Phytopathology 82:1297-1301.

20. Liu, Z. L., and Sinclair, J. B. 1993. Colonization of soybean roots by Bacillus megaterium B153-2-2. Soil Biol. Biochem. 25:849-855.

21. Logan, N. A., and Berkeley, R. C. W. 1984. Identification of Bacillus strains using the API system. J. Gen. Microbiol. 130:1871-1882.

22. Mahaffee, W. F., and Backman, P. A. 1993. Effects of seed factors on spermosphere and rhizosphere colonization of cotton by Bacillus subtilis GB03. Phytopathology 83:1120-1125.

23. Maplestone, P. A., and Campbell, R. 1989. Colonization of roots of wheat seedlings by bacilli proposed as biocontrol agents against take-all. Soil Biol. Biochem. 21:543-550.

24. Martin, J. K. 1975. Comparison of agar media for counts of viable soil bacteria. Soil Biol. Biochem. 7:401-402.

25. Mavingui, P., Laguerre, G., Berge, O., and Heulin, T. 1992. Genetic and phenotypic diversity of Bacillus polymyxa in soil and in the wheat rhizosphere. Appl. Environ. Microbiol. 58:1894-1903.

26. Mazzola, M., and Cook, R. J. 1991. Effects of fungal root pathogens on the population dynamics of biocontrol strains of fluorescent pseudomonads in wheat rhizosphere. Appl. Environ. Microbiol. 57:2171-2178.

27. Mazzola, M., Wong, O. T., and Cook, R. J. 1996. Virulence of Rhizoctonia oryzae and $R$. solani AG-8 on wheat and detection of $R$. oryzae in plant tissue by PCR. Phytopathology 86:354-360.

28. Merriman, P. R., Price, R. D., Baker, K. F., Kollmorgen, J. F., Piggott, T., 
and Ridge, E. H. 1975. Effect of Bacillus and Streptomyces spp. applied to seed. Pages 130-133 in: Biology and Control of Soil-Borne Plant Pathogens. G. W. Bruehl, ed. The American Phytopathological Society, St. Paul, MN.

29. Moore, K. J., and Cook, R. J. 1984. Increased take-all of wheat with direct drilling in the Pacific Northwest. Phytopathology 74:1044-1049.

30. Ogoshi, A., Cook, R. J., and Basset, E. N. 1990. Rhizoctonia species and anastomosis groups causing root rot of wheat and barley in the Pacific Northwest. Phytopathology 80:784-788.

31. Ownley, B. H., Weller, D. M., and Thomashow, L. S. 1992. Influence of in situ and in vitro $\mathrm{pH}$ on suppression of Gaeumannomyces graminis var. tritici by Pseudomonas fluorescens 2-79. Phytopathology 82:178-184.

32. Pierson, E. A., and Weller, D. M. 1994. Use of mixtures of fluorescent pseudomonads to suppress take-all and improve the growth of wheat. Phytopathology 84:940-947.

33. Pierson, L. S., III, and Thomashow, L. S. 1992. Cloning and heterologous expression of the phenazine biosynthetic locus from Pseudomonas aureofaciens 30-84. Mol. Plant-Microbe Interact. 5:330-339.

34. Roget, D. K., Neate, S. M., and Rovira, A. D. 1996. The effect of sowing point design and tillage practice on the incidence of Rhizoctonia root rot, take-all, and cereal cyst nematode. Aust. J. Exp. Agric. 36:683-693.

35. Roget, D. K., Venn, N. R., and Rovira, A. D. 1987. Reduction of Rhizoctonia root rot of direct-drilled wheat by short-term chemical fallow. Aust. J. Exp. Agric. 27:425-430.

36. Rovira, A. D. 1986. Influence of crop rotation and tillage on Rhizoctonia bare patch of wheat. Phytopathology 76:669-673.

37. Ryder, M. H., and Rovira, A. D. 1993. Biological control of take-all of glasshouse-grown wheat using strains of Pseudomonas corrugata isolated from wheat field soil. Soil Biol. Biochem. 25:311-320.

38. Smiley, R. W., Ogg, A. G., Jr., and Cook, R. J. 1992. Influence of glyphosate on severity of Rhizoctonia root rot, growth, and yield of barley. Plant Dis. 76:937-942.

39. Smiley, R. W., and Uddin, W. 1993. Influence of soil temperature on Rhizoctonia root rot ( $R$. solani AG-8 and $R$. oryzae) of winter wheat.
Phytopathology 83:777-785.

40. Sneath, P. H. A. 1986. Endospore forming gram-positive rods and cocci. Pages 1104-1137 in: Bergey's Manual of Systematic Bacteriology Vol. 2. N. R. Krieg and J. G. Holt, eds. Williams and Wilken, Baltimore, MD.

41. Thomashow, L. S., Weller, D. M., Bonsall, R. F., and Pierson, L. S., III 1990. Production of the antibiotic phenazine-1-carboxylic acid by fluorescent Pseudomonas species in the rhizosphere of wheat. Appl. Environ. Microbiol. 56:908-912.

42. Vidaver, A. K. 1967. Synthetic and complex media for rapid detection of fluorescence of phytopathogenic pseudomonads: Effect of carbon source. Appl. Microbiol. 15:1523-1524.

43. Vincent, M. N., Harrison, L. A., Brackin, J. M., Kovacevich, P. A., Mukerji, P., Weller, D. M., and Pierson, E. A. 1991. Genetic analysis of the antifungal activity of a soilborne Pseudomonas aureofaciens strain. Appl. Environ. Microbiol. 57:2928-2934.

44. Weller, D. M. 1988. Biological control of soilborne plant pathogens in the rhizosphere with bacteria. Annu. Rev. Phytopathol. 26:379-407.

45. Weller, D. M., and Cook, R. J. 1983. Suppression of take-all of wheat by seed treatments with fluorescent pseudomonads. Phytopathology 73:463-469.

46. Weller, D. M., Cook, R. J., MacNish, G., Bassett, E. N., Powelson, R. L., and Petersen, R. R. 1986. Rhizoctonia root rot of small grains favored by reduced tillage in the Pacific Northwest. Plant Dis. 70:70-73.

47. Weller, D. M., and Thomashow, L. S. 1993. Use of rhizobacteria for biocontrol. Curr. Opin. Biotechnol. 4:306-311.

48. Weller, D. M., Zhang, B.-X., and Cook, R. J. 1985. Application of a rapid screening test for selection of bacteria suppressive to take-all of wheat. Plant Dis. 69:710-713.

49. Wilkinson, H. T., Cook, R. J., and Alldredge, J. R. 1985. Relation of inoculum size and concentration to infection of wheat roots by Gaeumannomyces graminis var. tritici. Phytopathology 75:98-103.

50. Zhang, S., Xu, W., Yan, Z., and Mei, R. 1996. Research and commercialization of yield-increasing bacteria in China. Pages 47-53 in: Advances in Biological Control of Plant Diseases. W. h. Tang, R. J. Cook, and A. D. Rovira, eds. China Agric. Univ. Press, Beijing, China. 